THE COLLAPSE OF THE SPANISH REPUBLIC, 1933-1936 



\section{The Collapse of the} Spanish Republic,

I933-1936

ORIGINS OF THE CIVIL WAR 
Copyright (C) 2006 by Stanley G. Payne

All rights reserved.

This book may not be reproduced, in whole or in part, including illustrations, in any form (beyond that copying permitted by Sections Io7 and Io8 of the U.S. Copyright Law and except by reviewers for the public press), without written permission from the publishers.

Set in FontShop Scala by Duke \& Company, Devon, Pennsylvania.

Printed in the United States of America.

Library of Congress Cataloging-in-Publication Data

Payne, Stanley G.

The collapse of the Spanish Republic, I933-1936 : origins of the Civil War /

Stanley G. Payne.

p. $\mathrm{cm}$.

Includes bibliographical references and index.

ISBN-I3: 978-0-300-II065-4 (alk. paper)

ISBN-I0: 0-300-IIo65-0 (alk. paper)

I. Spain-History-Republic, I93I-I939. 2. Representative government and representation-Spain-History—2oth century. I. Title.

DP254.P37 2006

$946.08 \mathrm{I}^{\prime} \mathrm{I}-\mathrm{dc} 22$

2005023407

A catalogue record for this book is available from the British Library.

The paper in this book meets the guidelines for permanence and durability of the Committee on Production Guidelines for Book Longevity of the Council on Library Resources.

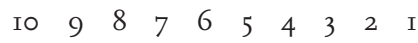


To Adolfo Suárez and the leaders and members of Unión de Centro Democrático, who demonstrated how to construct a democracy in Spain.

Their history was brief, but glorious. 
